\title{
THE EFFECT OF DREISSENA POLYMORPHA ON BACTERIOPLANKTON, NEMATODE FAUNA AND THEIR RELATIONS TO ENVIRONMENTAL FACTORS IN OGOSTA RESERVOIR (DANUBE BASIN)
}

Hristina KALCHEVA *, Stefan STOICHEV *, Mihaela BESHKOVA *, Roumen KALCHEV *, Marieta STANCHKOVA *, Dimitar KOZUHAROV ** and Teodora TRICHKOVA *

* Bulgarian Academy of Sciences, Institute of Biodiversity and Ecosystem Research, Tsar Osvoboditel Boulevard 1, Sofia, Bulgaria,BG-1000, hristinakalcheva@yahoo.com, stefanstoichev@yahoo.com, beshkova_m@yahoo.com, roumenkalchev@hotmail.com, trichkova@gmail.com

** Sofia University “St. Kliment Ohridski”, Faculty of Biology, Dragan Tsankov Boulevard 8, Sofia, Bulgaria, BG-1164, etipost@dir.bg,mitko_bf@abv.bg

DOI: 10.1515/trser-2015-0077

KEYWORDS: bacterioplankton, Dreissena polymorpha, nematodes, Bulgaria.

\section{ABSTRACT}

Spatial, seasonal, and annual bacterioplankton dynamics in recently infested by the species Dreissena polymorpha Ogosta Reservoir were studied for the first time during three year period. Bacterioplankton total number was higher in spring in ecotone zones, than in summer at thermocline. $\mathrm{NH}_{4}-\mathrm{N}, \mathrm{PO}_{4}-\mathrm{P}$, turbidity, dissolved oxygen, $\mathrm{COD}$ and chlorophyll-a correlate positively, while transparency and $\mathrm{Ca}^{2+}$ negatively with bacteria. Nematode species composition, included 22 species studied (13 rarely found and Rhabditis brevispina new for Bulgaria) belonging to nine families. The $D$. polymorpha impact is positive on nematodes and phytoplankton, negative on zooplankton and bacterioplankton, but weak positive on larger bacteria, rods and attached bacteria.

RESUMEN: Efecto de Dreissena polymorpha en el bacterioplancton y la fauna de nemátodos y su relación con factores ambientales en el Reservorio Ogosta.

Por primera vez se estudia la dinámica espacial y estacional del bacterioplancton durante una invasión reciente de la especie Dreissena polymorpha en el Reservorio Ogosta, a lo largo de tres años. En términos numéricos, el bacterioplancton fue más abundante en los ecotonos durante la primavera y durante el verano en la termoclina. Los $\mathrm{NH}_{4}-\mathrm{N}, \mathrm{PO}_{4}-\mathrm{P}$, la turbidez, oxígeno disuelto, COD y la clorofila-a mostraron una correlación positiva con la abundancia de bacterias, en tanto que la transparencia y el $\mathrm{Ca}^{2+}$ se correlacionaron negativamente. La composición de especies de nemátodos, que también estudiada por primera vez, incluye 22 especies (13 raramente encontradas y Rhabditis brevispina, una especie nueva para Bulgaria) pertenecientes a nueve familias. El impacto de D. polymorpha es positivo sobre los nemátodos y el fitoplancton, pero negativo sobre el bacterioplancton y el zooplancton; se encontró una relación débil con las bacterias de gran tamaño y con aquellas que tienden a adherirse.

REZUMAT: Efectul speciei Dreissena polymorpha asupra bacterioplanctonului, faunei de nematode şi relațiilor acestora cu factorii de mediu în lacul de acumulare Ogosta.

A fost studiată în trei ani, dinamica spaţială, sezonieră şi anuală a bacterioplanctonului în recentul invadat bazin Ogosta de către specia Dreissena polymorpha. Numărul total al bacterioplanctonului a fost mai mare primăvara în zonele de ecoton, decât vara la termoclină. $\mathrm{NH}_{4}-\mathrm{N}, \mathrm{PO}_{4}-\mathrm{P}$, turbiditatea, oxigenul dizolvat, $\mathrm{CCO}$ şi clorofila-a s-au corelat pozitiv, în timp ce transparenţa şi $\mathrm{Ca}^{2+}$ s-au corelat negativ cu bacteriile. Compoziţia speciilor de nematode, studiate pentru prima oară, include 22 de specii (13 rare şi Rhabditis brevispina nouă pentru Bulgaria) aparţinând la nouă familii. $D$. polymorpha are un impact pozitiv asupra nematodelor şi fitoplanctonului, negativ asupra zooplanctonului şi bacterioplanctonului, dar uşor pozitiv asupra bacteriilor mai mari, a bacililor şi a biofilmului. 


\section{INTRODUCTION}

The investigation of Dreissena polymorpha (Pallas, 1771) effect on reservoir ecosystems is very important, especially for countries like Bulgaria, where main freshwater resources are in reservoirs built on rivers (Kalchev et al., 2013). Dreissena ssp. (D. polymorpha and $D$. bugensis, Bivalvia: Dreissenidae) are known as successful aquatic invaders that have great potential to directly or indirectly impact the biodiversity and ecosystem functioning. Due to their ability to filter the seston in large volumes of water, they cause huge ecosystem changes summarized as a shift of energy flow from pelagic to benthic food chain (Karatayev et al., 2002). Factors that limit the growth and spread of the invasive species $D$. polymorpha include low and high temperatures (below $10^{\circ} \mathrm{C}$ or above $26-32^{\circ} \mathrm{C}$ ), low concentration of calcium ions $\left(\mathrm{Ca}^{2+}\right)$, and very high or very low production in lakes (Strayer, 1991). In Bulgaria the species is found at depths between three $\mathrm{m}$ to $10 \mathrm{~m}$ in reservoirs with moderate amounts of nutrients (Trichkova et al., 2008; Kozuharov et al., 2009).

Planktonic bacteria are important for nutrient remineralisation and participate as a key trophic source in pelagic food webs (Straškrabova et al., 1999; Cotner and Biddanda, 2002; Jürgens and Matz, 2002; Pernthaler, 2005). The necessity of studying bacterioplankton development and its interaction with environmental factors, including some invasive species like zebra mussel (D. polymorpha) found in many lakes in the world, but also in Eastern Europe and in some Bulgarian reservoirs (Cotner et al., 1995; Karatayev et al., 1997; Trichkova et al., 2008; Kozuharov et al., 2009; Kozuharov and Stanachkova, 2015) is an indication of understanding the biogeochemical processes in aquatic ecosystems in the period of global warming and climate changes (Häder et al., 2007). It is found that the sizes and morphology of aquatic species are essential for trophic relationships between them (Havens, 1998), and bacterioplankton is without exception (Cotner et al., 1995; Cole, 1999; Hahn and Höfle, 2001; Pernthaler, 2005). Research for the ecological role of bacterioplankton in standing waters in Bulgaria is numerous (Beshkova et al., 2008; Kalcheva, 2011; etc.), but has not been performed in long-term experiments with inclusion of different trophic levels in reservoirs with the invasive species Dreissena polymorpha.

Free-living Nematoda play a main ecological role, as primary consumers displaying saprophagous or bacterivorous feeding habits, and take part in the nutrient cycling control. Data about Nematoda in Bulgaria was given by Valkanov (1934), Russev (1979) and Stoichev (1996, 1998). This study gives the first information about the free-living freshwater nematode of the Ogosta Basin and its relation to the environmental factors and Dreissena polymorpha.

This study establish the spatial, seasonal, and annual bacterioplankton dynamics and free-living nematode species diversity and to determine, the influence of environmental factors on them and the effect of Dreissena polymorpha occurrence on their development.

\section{MATERIAL AND METHODS}

The study was conducted in the period 2009-2011 in Ogosta Reservoir in Bulgaria, infested with the invasive species Dreissena polymorpha. The Ogosta Reservoir (Fig. 1) is situated in North-West Bulgaria close to the town of Montana at an altitude of $203 \mathrm{~m}$ a.s.l. $\left(43^{\circ} 22^{\prime} 31^{\prime \prime} \mathrm{N}, 23^{\circ} 10^{\prime} 56^{\prime \prime} \mathrm{E}\right)$. It is built on the river Ogosta, a direct tributary of the Danube River and gathers the waters of other two rivers, Zlatitsa and Barzeya. The reservoir area is 2,360 ha, its length by diagonal is $14 \mathrm{~km}$ and the total water volume is 506 million $\mathrm{m}^{3}$ (Kenderov et al., 2014). A total of 58 samples were taken for bacterioplankton in late summer of 2009 (in beginning of September), spring (April) and autumn (September/October) of 2010 and in summer (July) of 2011 from five stations (Fig. 1), divided from the wall (station 1) to the tail (station 5) of the reservoir and from different depth horizons starting at $0.3 \mathrm{~m}$ to maximum depth of each station, but one $\mathrm{m}$ above the bottom ( $35 \mathrm{~m}$ in station 1 , the wall). 


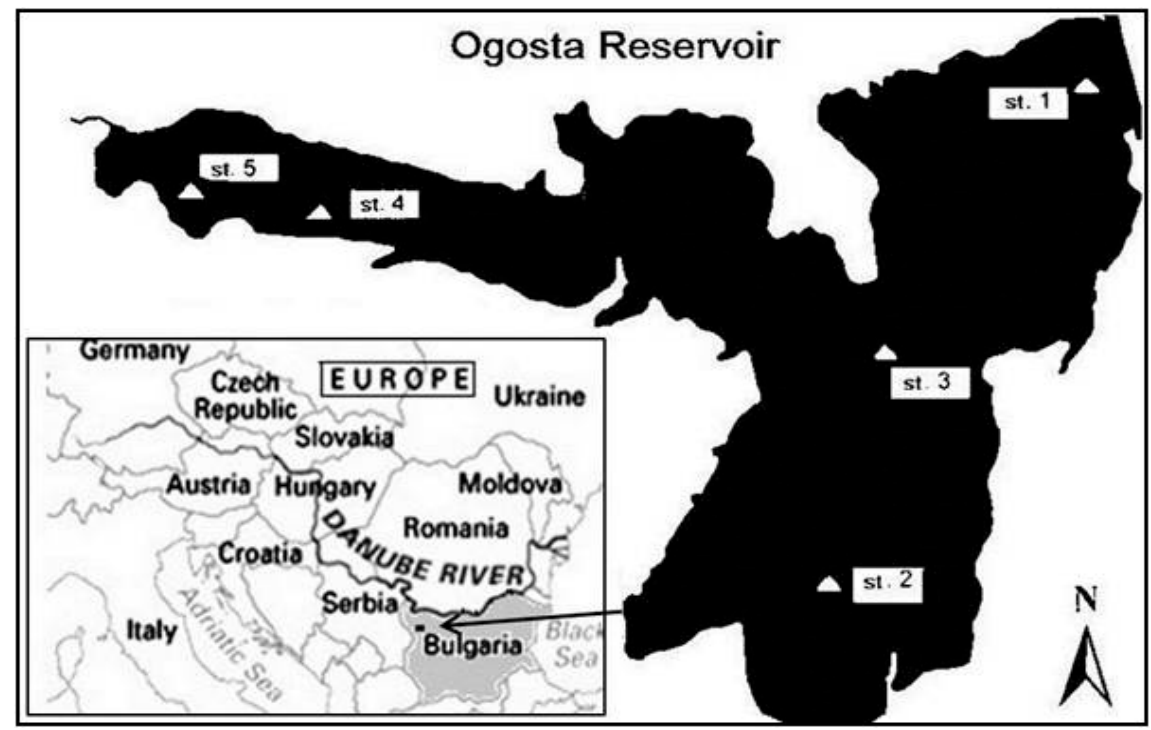

Figure 1: Overview of the study area in Bulgaria as a part of the Danube River basin countries in Europe and localisation of the measuring points (stations 1-5) in Ogosta Reservoir.

The number of bacteria is determined by the method of a direct count with a phasecontrast microscope (Carl Zeiss, Jena, Germany) by the ocular grid at a magnification of $1,600 \mathrm{x}$ after preliminary fixation with $2 \%$ formalin and staining with erythrosine (Razumov's method, updated by Naumova in Grudeva et al., 2006), described in detail (Kalcheva et al., 2008; Kalcheva, 2011). Biomass is calculated in carbon content by Norland's formula (Straškrabova et al., 1999) after determination of the mean cell volume (MCV). Bacterioplankton is counted separately for cells (cocci and rods) freely dispersed on the filter $(0.2 \mu \mathrm{m}$ pore size) and for cells that are associated with detritus particles, since morphological groups are provisionally divided in four groups (free cocci, rods and attached cocci, rods). The sizes of bacteria are divided into size classes (Pernthaler et al., 1996; Kalcheva et al., 2008; Chróst et al., 2009). The number of detritus particles with attached bacteria is also counted.

The material for free-living nematodes was collected with Ekman-Birge grab in spring, summer, and autumn of 2010 and in the summer of 2011. A total of 25 samples were collected. The results were adjusted for one $\mathrm{m}^{2}$. The nematode samples were rinsed on sieves, with mesh sizes of $500 \mu \mathrm{m}$ and $50 \mu \mathrm{m}$. A careful heating up to $60^{\circ} \mathrm{C}$ was performed, by which the nematodes become stacked and erected and thus convenient for measuring. Then the nematodes were fixed in 4\% formalin. Nematodes were identified according to Gagarin (1981) and measured on the basis of the formula of De Man (1886). The monograph of Loof (1999) was also used to determine the nematodes.

Parallel measurements for the three year period were made for 15 environmental factors, in situ for some physicochemical factors and hydrochemical sampling for laboratory analyses, also for chlorophyll-a and D. polymorpha, but only in 2009 for phytoplankton and zooplankton. Abiotic factors temperature, $\mathrm{pH}$, dissolved oxygen, and oxygen saturation are measured with oximeter type WTW 315i/SET, transparency by Secchi disc, $\mathrm{Ca}^{2+}$ by a standard method in a chemical laboratory at the University of Innsbruck. The other factors, $\mathrm{NH}_{4}-\mathrm{N}$, $\mathrm{NO}_{3}-\mathrm{N}, \mathrm{NO}_{2}-\mathrm{N}, \mathrm{PO}_{4}-\mathrm{P}, \mathrm{TN}, \mathrm{TP}, \mathrm{Fe}, \mathrm{Si}$, and COD are analyzed with kits of Merck (Germany) and by a spectrophotometer Spectroquant ${ }^{\circledR}$ NOVA60 and a thermoreactor (Merck, Bulgaria 
EAD). Standard methods for phytoplankton (Beshkova et al., 2008), zooplankton (Kozuharov and Stanachkova, 2015), chlorophyll-a (ISO 10260, 1992) and D. polymorpha are used (Trichkova et al., 2008). Quantitative results about Dreissena polymorpha have not been presented and used in this study, but only the assessment of its development in five categories (absent, only shells, small, middle and high quantities) from the five stations and the sampling depths is performed for statistical analyses. Data of all environmental factors, abiotic and biotic, are also not presented, but only used in statistical analyses.

The multivariate statistical Redundancy Analysis (RDA) with the program CANOCO for Windows 4.5 (ter Braak and Smilauer, 2002), single factor analysis of variance (one-way ANOVA), nonparametric correlations of Spearman $\left(\mathrm{R}_{\mathrm{Sp}}\right)$ and regressions (linear correlations) with the computer program STATISTICA 7.0 are used. Bacterioplankton variables are included in RDA as dependent (response) variables, while environmental factors (abiotic, biotic and the zebra mussel) as independent (explanatory) variables. Where RDA includes Nematoda species as dependent variables, bacteria are presented as independent. Statistical evaluations are performed using a level of significance $\mathrm{P}$ (probability) with $5 \%$ risk of error ( $\alpha$ or $\mathrm{P}<0.05)$.

\section{RESULTS AND DISCUSSION}

The total number of bacterioplankton in the period 2009-2011 varied in the range from $4.70 \times 10^{4}$ to $5.83 \times 10^{5}$ cells.ml $^{-1}$ (Fig. 2). The biomass in carbon content varied from 0.69 to $10.24 \mu \mathrm{g} \mathrm{C.} \mathrm{L}^{-1}$ and the mean cell volume (MCV) was in the range between 0.0493 and $0.0797 \mu \mathrm{m}^{3}$ (Fig. 3). The abundance was higher than in other studied reservoirs (Beshkova et al., 2008; Kalcheva, 2011). Abundance and biomass decreased towards 2011, but were higher in spring in stations close to inflows of the main and other two rivers (ecotone zones, 2 and 5), and in summer at the deeper layers with a maximum at thermocline (at a depth of $15 \mathrm{~m}$ ) in the deepest station 1 (the wall) and at five $m$ in other stations (Figs. 3 and 4), where the organic matter and biodegradation increased. The differences between the seasons were statistically significant (Fig. 3, ANOVA), between the years they were close to the level of significance $(p=0.07)$, while between the five stations they were not significant. The MCV was relatively low with the dominance of the smallest size class of $0.2-0.5 \mu \mathrm{m}(49-83 \%$ of the total). This is typical for eutrophic waters (Šimek et al., 1997; Pernthaler et al., 1996; Chróst et al., 2009).

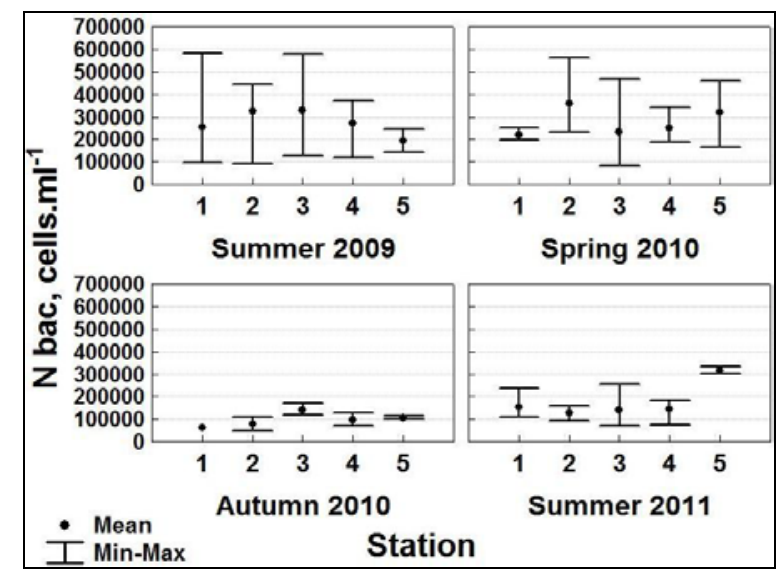

Figure 2: Spatial, seasonal and annual dynamics of bacterioplankton total number (mean, minimum and maximum) at sampling stations (1-5) in the Ogosta Reservoir during 2009-2011. 
Free-living cocci were $24-59 \%$ and prevailed over the other morphotypes, but larger bacteria $(<$ one $\mu \mathrm{m})$ and bigger quantities of attached to detritus bacteria were found in 20092010 when the development of $D$. polymorpha was stronger than in 2011. The attached bacteria varied widely from three to $80 \%$ and were higher in summer. Most probably it is connected with the organic matter excreted by the zebra mussels, and also with their filtration of small sized seston including bacteria (Cotner et al., 1995; Dionisio Pires et al., 2004). The number of free-living large bacteria were higher in spring especially in stations 2 and 5, ecotone zones, where the inflows of the rivers (probably due to the rainfalls), had more organic matter and nutrients. The increase in the quantity of rod cells, especially with the relatively large sizes means, increased organic content in the water (Pernthaler, 2005). The detritus particles number was higher in 2009 summer in station 2 and at the depth layers between $0.3 \mathrm{~m}$ and $15 \mathrm{~m}$. We assume that the reason, again, is excreted organic matter by $D$. polymorpha.

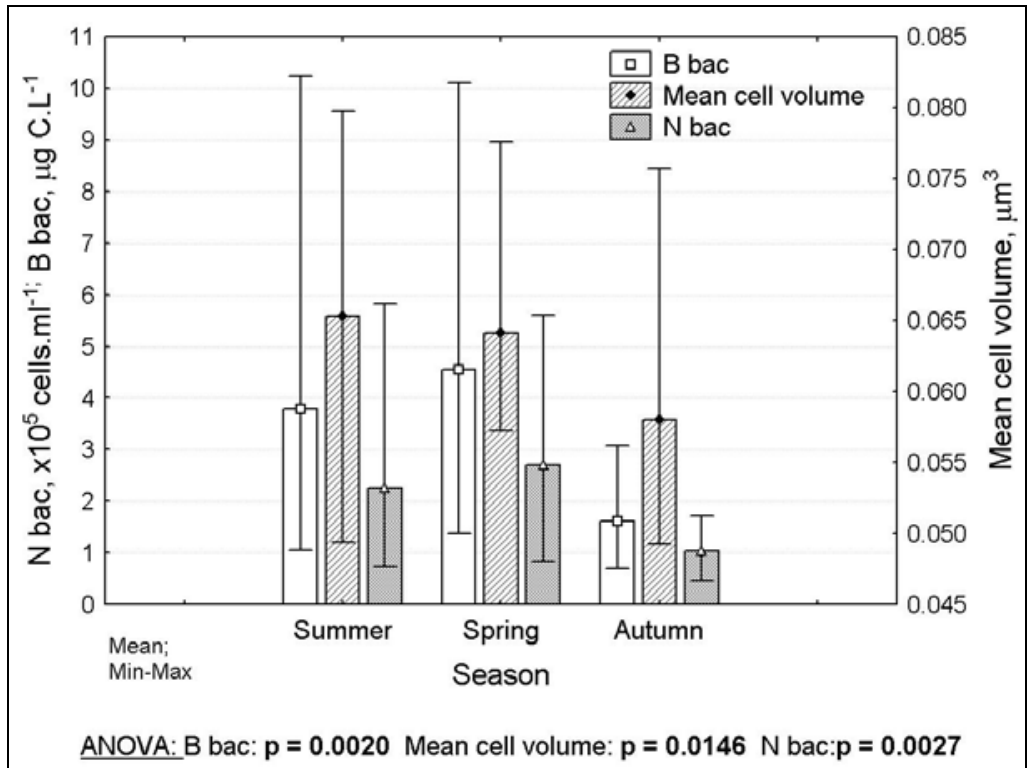

Figure 3: Seasonal dynamics of bacterioplankton total number, biomass and mean cell volume (mean, min-max) in Ogosta Reservoir for the three year period (2009-2011) and f-test with given p-values (ANOVA).

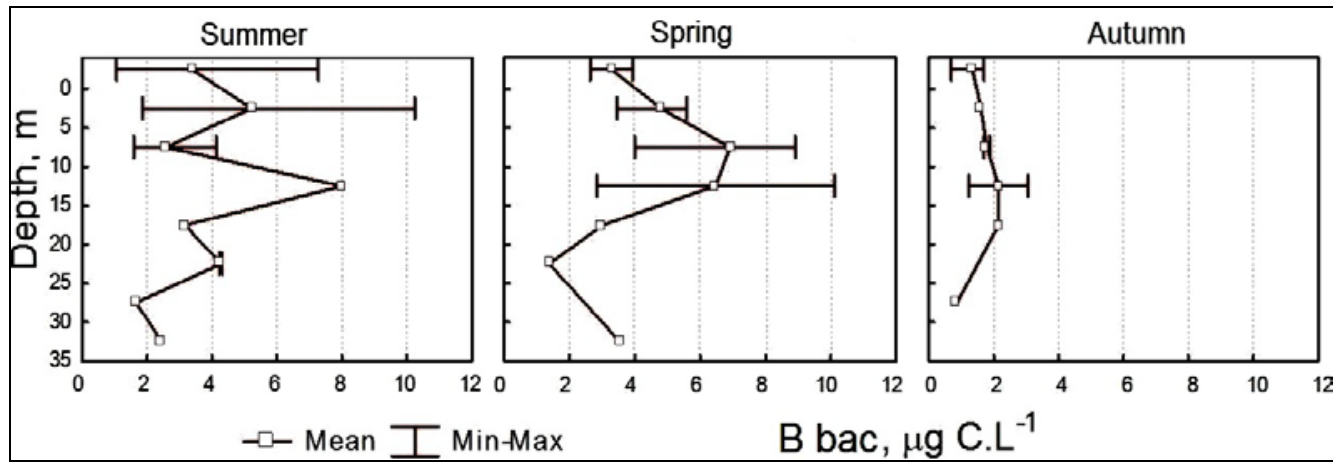

Figure 4: Seasonal dynamics of the bacterial biomass (B bac) in different depth layers in Ogosta Reservoir in the period 2009-2011. 
22 species from 12 genera, nine families, and five orders were determined in Ogosta Reservoir (Tab. 1). The species Monhystera stagnalis, Monhystera filiformis and Dorylaimus stagnalis were found in all sites. One species (Rhabditis brevispina, marked by + ) is new to the Bulgarian hydrofauna. The Nematoda diversity in Zhrebchevo Reservoir (Stoichev and Danova, 2012), 26 species, was close to the species number in Ogosta Reservoir, both infested by Dreissena polymorpha. While in the non-infested Koprinka Reservoir and Stambolijski Reservoir the species number is lower, 15 and 11 respectively (Stoichev, 1996). The number of species that we found is close to the data given by Traunspurger (2002), who reported that the species richness in general ranges between 30 and 70 in lakes and rivers. The results from the dominance analysis of the species ( $\mathrm{pF}, \mathrm{DF}$ and $\mathrm{Dt}$ in \%) are shown in table 1 . Beside species with high values of frequency of occurrence and range of dominance (Monhystera stagnalis, Monhystera filiformis, Dorylaimus stagnalis), are also species with high values of range of dominance, low frequency of occurrence, and frequency of dominance can be found (Cylindrolaimus communis, Rhabditis filiformis, Prodesmodora circulata).

In 2009-2011 for D. polymorpha and D. bugensis (Andrusov, 1897, the impact was not assessed in this study, see in Stanachkova et al., 2015), were found at a depth of 0.30 to $30 \mathrm{~m}$. D. polymorpha more often was found at depths up to $15 \mathrm{~m}$, while $D$. bugensis, which is deepwater species, at 24-30 meters (at station 1, the wall). According to the measured temperature (7-29 ${ }^{\circ} \mathrm{C}$, but except the extreme values) and chl-a (0.7-8.9 $\mu \mathrm{g} . \mathrm{L}^{-1}$, mesotrophy), Ogosta Reservoir is appropriate for the development of D. polymorpha (Strayer, 1991).

Table 1: Nematoda species by stations and dominant analysis (pF\%, DF\% and Dt\%).

\begin{tabular}{|c|c|c|c|c|c|c|c|c|}
\hline \multirow[b]{2}{*}{ Taxa } & \multicolumn{5}{|c|}{ Stations } & \multicolumn{3}{|c|}{ Dominant analysis } \\
\hline & 1 & 2 & 3 & 4 & 5 & $\begin{array}{l}\mathrm{pF} \\
\%\end{array}$ & $\begin{array}{l}\mathrm{D} \\
\%\end{array}$ & $\begin{array}{l}\mathrm{Dt} \\
\%\end{array}$ \\
\hline \multicolumn{9}{|l|}{ Monhysterida } \\
\hline \multicolumn{9}{|l|}{ Monhysteridae } \\
\hline Monhystera stagnalis Bastian, 1865 & $\mathrm{X}$ & $\mathrm{X}$ & $\mathrm{X}$ & $\mathrm{X}$ & $\mathrm{X}$ & 74.28 & 54.3 & 73.07 \\
\hline Monhystera filiformis Bastian, 1865 & $\mathrm{X}$ & $\mathrm{X}$ & $\mathrm{X}$ & & $\mathrm{X}$ & 62.85 & 51.4 & 81.81 \\
\hline Monhystera sp. & & & & $\mathrm{X}$ & & 2.85 & & \\
\hline \multicolumn{9}{|l|}{ Dorylaimida } \\
\hline \multicolumn{9}{|l|}{ Dorylaimidae } \\
\hline Dorylaimus stagnalis Dujardin, 1845 & $\mathrm{X}$ & $\mathrm{X}$ & $\mathrm{X}$ & $\mathrm{X}$ & $\mathrm{X}$ & 88.57 & 62.8 & 70.96 \\
\hline Dorylaimus sp. & & & $\mathrm{X}$ & & & 2.85 & & \\
\hline $\begin{array}{l}\text { Paradorylaimus filiformis } \\
\text { (Bastian, 1896) Andrassy, } 1969\end{array}$ & & & & $\mathrm{X}$ & & 5.71 & & \\
\hline Paradorylaimus sp. & & $\mathrm{X}$ & & & & 2.85 & & \\
\hline Mesodorylaimus sp. & & & $\mathrm{X}$ & & & 2.85 & & \\
\hline \multicolumn{9}{|l|}{ Qudsianematidae } \\
\hline $\begin{array}{l}\text { Eudorylaimus carteri } \\
\text { (Bastian, 1865) } \\
\text { Andrassy, 1969 } \\
\end{array}$ & $\mathrm{X}$ & & $\mathrm{X}$ & & $\mathrm{X}$ & 31.42 & 14.3 & 45.44 \\
\hline
\end{tabular}


Table 1 (continued): Nematoda species by stations and dominant analysis (pF\%, DF\% and $\mathrm{Dt} \%)$.

\begin{tabular}{|c|c|c|c|c|c|c|c|c|}
\hline \multirow[b]{2}{*}{ Taxa } & \multicolumn{5}{|c|}{ Stations } & \multicolumn{3}{|c|}{ Dominant analysis } \\
\hline & 1 & 2 & 3 & 4 & 5 & $\begin{array}{l}\mathrm{pF} \\
\%\end{array}$ & $\begin{array}{l}\mathrm{D} \\
\%\end{array}$ & $\begin{array}{l}\mathrm{Dt} \\
\%\end{array}$ \\
\hline \multicolumn{9}{|l|}{ Cylindrolaimidae } \\
\hline $\begin{array}{l}\text { Cylindrolaimus communis } \\
\text { De Man, } 1880\end{array}$ & & $\mathrm{X}$ & & & & 8.57 & 2.85 & 33.25 \\
\hline Cylindrolaimus sp. & & & & $\mathrm{X}$ & & 2.85 & & \\
\hline \multicolumn{9}{|l|}{ Plectidae } \\
\hline $\begin{array}{l}\text { Plectus cirratus } \\
\text { Bastian, } 1865\end{array}$ & & & $\mathrm{X}$ & $\mathrm{X}$ & & 22.85 & 17.1 & 75.01 \\
\hline $\begin{array}{l}\text { Plectus assimilis } \\
\text { Bütschlii, } 1873\end{array}$ & & $\mathrm{X}$ & & & & 5.71 & & \\
\hline \multicolumn{9}{|l|}{ Rhabditida } \\
\hline \multicolumn{9}{|l|}{ Rhabditidae } \\
\hline $\begin{array}{l}\text { Rhabditis filiformis } \\
\text { Bütschlii, } 1873\end{array}$ & $\mathrm{X}$ & $\mathrm{X}$ & & & & 17.14 & 11.4 & 66.62 \\
\hline $\begin{array}{l}\text { Rhabditis brevispina } \\
\text { (Claus, 1862) } \\
\text { Bütschlii, 1873 }\end{array}$ & & & $\mathrm{X}$ & & & 2.83 & & \\
\hline \multicolumn{9}{|l|}{ Enoplida } \\
\hline \multicolumn{9}{|l|}{ Tripylidae } \\
\hline $\begin{array}{l}\text { Tripyla glomerans } \\
\text { Bastian, } 1865\end{array}$ & $\mathrm{X}$ & & $\mathrm{X}$ & $\mathrm{X}$ & & 51.42 & 45.7 & 88.89 \\
\hline $\begin{array}{l}\text { Tobrilus gracilis } \\
\text { Bastian, } 1865\end{array}$ & & & $\mathrm{X}$ & & & 11.42 & & \\
\hline Tobrilus sp. & & & $\mathrm{X}$ & & & 2.85 & & \\
\hline \multicolumn{9}{|l|}{ Enoplidae } \\
\hline $\begin{array}{l}\text { Tobrilus gracilis } \\
\text { Bastian, } 1865\end{array}$ & & & $\mathrm{X}$ & & & 11.42 & & \\
\hline Tobrilus sp. & & & $\mathrm{X}$ & & & 2.85 & & \\
\hline \multicolumn{9}{|l|}{ Enoplidae } \\
\hline $\begin{array}{l}\text { Enoploides fluviatilis } \\
\text { Micoletzky (1923) }\end{array}$ & $\mathrm{X}$ & $\mathrm{X}$ & & $\mathrm{X}$ & & 14.28 & 5.71 & 39.98 \\
\hline Enoploides sp. & & $\mathrm{X}$ & & & & 2.85 & & \\
\hline \multicolumn{9}{|l|}{ Chromadorida } \\
\hline \multicolumn{9}{|l|}{ Microlaimidae } \\
\hline $\begin{array}{l}\text { Prodesmodora circulata } \\
\text { (Micoletzky, 1913) } \\
\text { Micoletzky, 1915 }\end{array}$ & & $\mathrm{X}$ & $\mathrm{X}$ & $\begin{array}{l}8.5 \\
7\end{array}$ & $\begin{array}{l}2.8 \\
5\end{array}$ & 33.25 & & \\
\hline Prodesmodora sp. & & & & $\mathrm{X}$ & & 2.85 & & \\
\hline
\end{tabular}




\section{Interactions of bacterioplankton and nematodes with environmental factors and the effect of $D$. polymorpha occurrence}

From environmental factors, mainly abiotic, positive relationships exist between bacterioplankton and nutrients, $\mathrm{NH}_{4}-\mathrm{N}(\mathrm{r}=0.38), \mathrm{PO}_{4}-\mathrm{P}(\mathrm{r}=0.34)$, TP, turbidity, dissolved oxygen, Fe ions, COD (Fig. 5B), phytoplankton biomass $(\mathrm{r}=0.58)$, and chlorophyll-a. Negative relations are found with $\mathrm{pH}$, transparency (Fig. 5A), and $\mathrm{Ca}^{2+}(\mathrm{r}=-0.33)$. The ratio of the nutrients $\mathrm{N}$ and $\mathrm{P}$ is very important for bacterioplankton development (Vadstein et al., 2003; Chróst et al., 2009). Temperature, in most cases, shows negative relation with bacteria except cell volume (sizes), but probably is very high and beyond the optimum under conditions of global warming and shallowness of the water bodies, which affects all organisms.

A negative correlation existed between $D$. polymorpha and the bacterial abundance (and biomass) in 2009, while in 2010-2011 it was positive, close to the level of significance with p-value $=0.08$ and p-value $=0.07$ respectively (RDA, Fig. 5A, B). Negative correlations were confirmed, also by nonparametric tests, for the whole period (2009-2011) as weak, but significant of $D$. polymorpha with bacterioplankton abundance $\left(\mathrm{r}_{\mathrm{Sp}}=-0.287\right)$ and biomass $\left(r_{S p}=-0.298\right)$. The results are in agreement with previous findings reported in similar studies. We assume that the increase of larger sized free-living bacteria in Ogosta Reservoir is related to the findings of Dionisio Pires et al. (2004) about preferential filtration by $D$. polymorpha of two seston size groups, $0-1 \mu \mathrm{m}$ and $30-100 \mu \mathrm{m}$. Filtration by zebra mussels of free-living bacteria with sizes under one $\mu \mathrm{m}$ leads to better transparency and that is pointed out with the positive relation of $D$. polymorpha with transparency, and negative with bacteria (Fig. 5A).

The relation of bacterioplankton with the other two plankton communities (Fig. 5A), determined in 2009, showed a positive correlation with phytoplankton biomass (due to extracellular release of DOC), but negative with zooplankton number (due to predation). The effect of $D$. polymorpha on the plankton was positive impact on phytoplankton number, but negative on zooplankton number, bacterioplankton number, and biomass (Fig. 5A).

Two important environmental factors, COD and oxygen saturation, correlated significantly to the spatial diversity of nematode species (RDA, $\mathrm{p}=0.026$, not shown). Bacterioplankton total number and COD (Fig. 5B) had higher values in stations 2 and 5. These stations represent ecotone zones, because of the inflow of the rivers Zlatitsa and Barzeya and respectively Ogosta, where the quantity of dead organic matter coming from the rivers to the reservoir, is higher and the processes of its degradation is more intensive.

Negative correlations were found between bacteria and Tripyla glomerans $(\mathrm{r}=-0.98$, $\mathrm{p}=0.002$, T. glomerans $=36,0076-0,0001 * \mathrm{x})$ and between detritus and Enoploides fluviatilis $\left(\mathrm{r}_{\mathrm{sp}}=-0.88, \mathrm{p}<0.05\right)$. Tobrilus genus was found in the sampling station 3 and correlated negatively with the oxygen saturation. The individuals of Tobrilus are represented at a high density in the sediments of lenthic ecosystems, especially in eutrophic lakes (Traunspurger, 2002), and are considered as tolerant of low oxygen conditions (Vidakovic and Bogut, 2004). Positive correlations were found between D. polymorpha and M. filiformis and $R$. filiformis (Fig. 5B), most probably utilizing detritus particles excreted by the zebra mussels. 


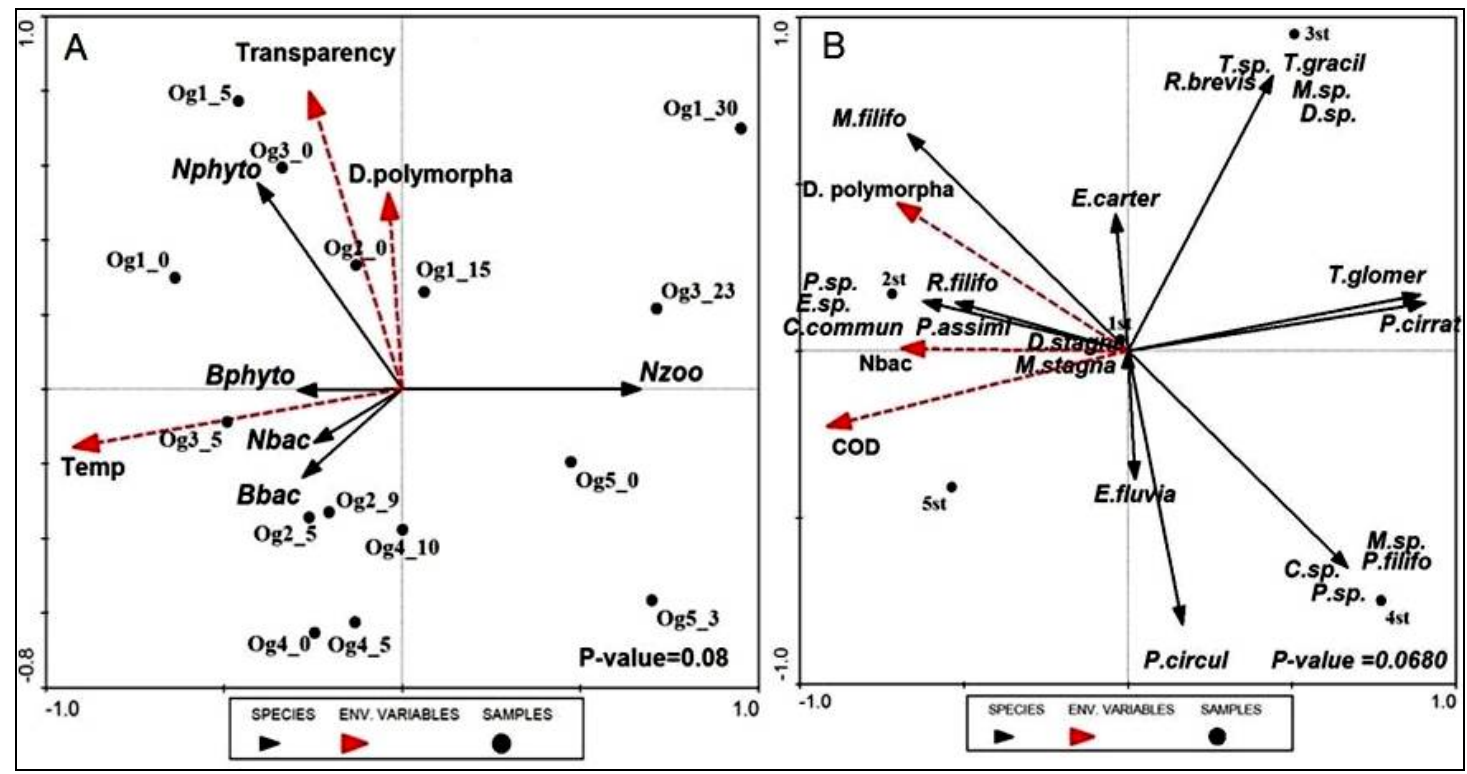

Figure 5: RDA triplots presenting the correlations (with given p-values) between:

(A) bacterioplankton, phytoplankton and zooplankton (dependent variables, species) and environmental factors and $D$. polymorpha (env. variables) by stations and depth horizons (samples) in 2009,

(B) Nematode species composition (species) and environmental factors, bacterioplankton and D. polymorpha (env. variables) by stations (samples) in 2010-2011. Abbreviations: N number, B - biomass, bac - bacterioplankton, phyto - phytoplankton, zoo - zooplankton, COD - chemical organic demand, st - stations from 1 to 5; coding of Og2_5 = Og (Ogosta), 2 (the station number), 5 (from five $\mathrm{m}$ depth); for full names of Nematode species see in table 1.

\section{CONCLUSIONS}

The effect of Dreissena polymorpha on bacterioplankton in investigated Ogosta Reservoir is indirect, manifested with higher bacterial abundance, due to weakened zooplankton pressure. Direct effects are a slightly negative impact on the number and biomass (during the whole period), and a slightly positive impact on larger bacteria, rods, and attached bacteria.

The effect of Dreissena polymorpha on phytoplankton, transparency and COD, is positive, but leading to eutrophication and more organic matter, while it is negative on zooplankton, leading indirectly to lower fish production and diversity.

The Nematoda community in the ecosystem of Ogosta Reservoir is composed of species with high ecological valence as well as species with different level of specialization and adaptation to the environmental conditions, and also to the infestation of the invasive species Dreissena polymorpha. Nematode species richness is higher than in others studied, not in investigated reservoirs in Bulgaria, proving prosperity of detritivores in the invested reservoir. Nematodes species richness is higher than in others in Bulgarian reservoirs, proving prosperity of detritivores in this studied case. 


\section{ACKNOWLEDGEMENTS}

The study was funded by the Bulgarian National Science Fund within the project DO 02-358/2008 and was supported by the Financial Mechanism of the European Economic Area (2009-2014), Programme BG03 Biodiversity and Ecosystem Services, Project ESENIASTOOLS, D-33-51/30.06.2015. 


\section{REFERENCES}

1. Beshkova M., Kalcheva H. and Kalchev R., 2008 - Phytoplankton and bacterioplankton in three reservoirs (North-East Bulgaria) recommended as potential reference sites according to the Water Framework Directive of EU, Acta Zoologica Bulgarica, 2, 165-174.

2. Chróst R., Adamczewski T., Kalinowska K. and Skowronska A., 2009 - Inorganic phosphorus and nitrogen modify composition and diversity of microbial communities in water of mesotrophic lake, Polish Journal of Microbiology, 58, 1, 77-90.

3. Cole J. J., 1999 - Aquatic microbiology for ecosystem scientists: new and recycled paradigms in ecological microbiology, Ecosystems, 2, 215-225.

4. $\quad$ Cotner J. B., Gardner W. S., Johnson J. R., Sada R. H., Cavaletto J. F. and Heath R. T., 1995 Effects of zebra mussels (Dreissena polymorpha) on bacterioplankton: evidence for sizeselective consumption and growth, Journal of Great Lakes Research, 21, 4, 517-528.

5. Cotner J. and Biddanda B., 2002 - Small players, large role: microbial influence on biogeochemical processes in pelagic aquatic ecosystems, Ecosystems, 5, 105-121.

6. De Man J., 1886 - Anatomical studies of free-living nematodes in North Sea, Paul Froberg, Leipzig, 82. (in German)

7. Dionisio Pires L., Jonker R., Van Donk E. and Laanbroek H., 2004 - Selective grazing by adults and larvae of the zebra mussel (Dreissena polymorpha): application of flow cytometry to natural seston, Freshwater Biology, 49, 116-126.

8. Gagarin V., 1981 - Identifier of freshwater nemadodes from the European part of SSSR, Nauka, St. Petersburg, 248. (in Russian)

9. Grudeva C., Moncheva P., Naumova S., Gocheva B., Nedeva T. and Antonova-Nikolova S., 2006 - Manual of Microbiology, University Press “St. Kl. Ohridski”, Sofia, 356. (in Bulgarian)

10. Hahn M. W. and Höfle M. G., 2001 - Grazing of protozoa and its effect on populations of aquatic bacteria, FEMS Microbiology Ecology, 35, 113-121.

11. Havens K. E., 1998 - Size structure and energetics in a plankton food web, Oikos, 81, 346-358.

12. Häder D.-P., Kumar H., Smith R. and Worrest R., 2007 - Effects of solar UV radiation on aquatic ecosystems and interactions with climate change, Photochemical and Photobiological Sciences, 6, 267-285.

13. ISO 10260, 1992 - Water quality. Measurement of biochemical parameters. Spectrometric determination of the chlorophyll-a concentration, 6 .

14. Jürgens K. and Matz C., 2002 - Predation as a shaping force for the phenotypic and genotypic composition of planktonic bacteria, Antonie van Leeuwenhoek, 81, 413-434.

15. Kalchev R., Beshkova M., Botev I., Kalcheva H., Kozuharov D. and Trichkova T., 2013 Effect of Dreissena polymorpha on physicochemical characteristics of Zhrebchevo Reservoir (Central Bulgaria), Proceedings of the Bulgarian Academy of Sciences, 66, 11, 1571-1578.

16. Kalcheva H., Nikolova L., Terziyski D., Stoeva A. and Kalchev R., 2008 - Relationships between bacterioplankton, zooplankton and environmental factors in fertilized and nonfertilized carp fish ponds, Acta Zoologica Bulgarica, 2, 175-184.

17. Kalcheva H. V., 2011 - Trophic significance of bacterioplankton in stagnant freshwater ecosystems - interactions with abiotic and biotic factors in the pelagial, $\mathrm{PhD}$ Thesis, Institute of Biodiversity and Ecosystem Research, BAS, Sofia, 203. (in Bulgarian, abstract in English)

18. Karatayev A. Y., Burlakova L. E. and Padilla D. K., 1997 - The effects of Dreissena polymorpha (Pallas) invasion on aquatic communities in Eastern Europe, Journal of Shellfish Research, 16, 1, 187-203.

19. Karatayev A., Burlakova L. E. and Padilla D. K., 2002 - Invasive aquatic species in Europe Leppaekovski E. et al. (eds), Kluwer Academic Publishers, Netherlands, 433-446.

20. Kenderov L., Pavlova M., Trichkova T., Tyufekchieva V., Vidinova Y., Kozuharov D., Botev I., Hubenov Z., Uzunov Y., Stoichev S., Beshkova M., Kalcheva H. and Kalchev R., 2014 Trophic state and trophic structure in three Bulgarian reservoirs, Acta Zoologica Bulgarica, 66, 2, 247-254. 
21. Kozuharov D., Trichkova T., Borisova P. and Stanachkova M., 2009 - The zooplankton composition in two reservoirs in the North-west Bulgaria in relation to Dreissena ssp. occurrence, Biotechnology and Biotechnological Equipment, 23, 271-275.

22. Kozuharov D. and Stanachkova M., 2015 - Long-term changes in zooplankton community in Zhrebchevo Reservoir, Central Bulgaria, Acta Zoologica Bulgarica, 67, 4, 541-552.

23. Loof P. A. A., 1999 - Nematoda, Adenophorea (Dorylaimida), in Schwoerbel J. and Zwick P. (eds), Freshwater fauna of Central Europe 4 (2-2), Spectrum Academic Publishers, 264. (in German)

24. Pernthaler J., 2005 - Predation on prokaryotes in the water column and its ecological implications, Nature Reviews Microbiology, 3, 537-546.

25. Pernthaler J., Sattler B., Šimek K., Schwarzenbacher A. and Psenner R., 1996 - Top-down effects on the size-biomass distribution of a freshwater bacterioplankton community, Aquatic Microbial Ecology, 10, 255-263.

26. Russev B., 1979 - Current knowledge of the species composition of zoobenthos of the Danube, in 19th Anniversary conference of IAD, Bulgaria (26.09.-02.10.1976, Sofia), 306-339. (in German)

27. Šimek K., Vrba J., Pernthaler J., Posch T., Hartman P., Nedoma J. and Psenner R., 1997 Morphological and compositional shifts in an experimental bacterial community influenced by protists with contrasting feeding modes, Applied and Environmental Microbiology, 63, 587595.

28. Stanachkova M., Kozuharov D., Zlatanova D. and Trichkova T., 2015 - Dynamics of Dreissena ssp. veliger larvae in some Bulgarian reservoirs, Biotechnology and Biotechnological Equipment, 29, 1, 27-32.

29. Stoichev S., 1996 - On the free-living nematode fauna from Bulgarian inland waters, Lauterbornia, 25, 22-30.

30. Stoichev S., 1998 - The zoobenthos from the Lakes Shabla-Ezerets (Northern Black Sea coast of Bulgaria), in Golemansky V. and Naidenow W. T. (eds), Biodiversity of the Shabla Lake system, "Marin Drinov" Academic Publishing House, 91-101.

31. Stoichev S. and Danova E., 2012 - Contribution to the study of the free-living freshwater Nematoda fauna of the Zhrebchevo Reservoir (South-East Bulgaria), Lauterbornia, 74, 129-133.

32. Straškrabová V., Callieri C., Carrillo P., Cruz-Pizarro L., Fott J., Hartman P., Macek M., Medina-Sánchez J. M., Nedoma J. and Šimek K., 1999 - Investigations on pelagic food webs in mountain lakes - aims and methods, Journal of Limnology, 58, 2, 77-87.

33. Strayer D. L., 1991 - Projected distribution of the zebra mussel, Dreissena polymorpha, in North America, Canadian Journal of Fisheries and Aquatic Sciences, 48, 1389-1395.

34. ter Braak C. J. F. and Smilauer P., 2002 - Canoco for Windows 4.5. Biometris, Wageningen and Ceske Budejovice, 484.

35. Traunspurger W., 2002 - Nematoda, in Rundle S. D., Robertson A. L. and Schmidaraya J. M. (eds), Freshwater meiofauna: biology and ecology, Backhuys Publishers, The Netherlands, 63-104.

36. Trichkova T., Kozuharov D., Hubenov Z., Botev I., Zivkov M. and Cheshmedjiev S., 2008 Characteristics of zebra mussel (Dreissena polymorpha) populations in infested reservoirs, Northwest Bulgaria, Journal of Natural History, 42, 5-8, 619-631.

37. Vadstein O., Olsen L., Busch A., Andersen T. and Reinertsen H., 2003 - Is phosphorus limitation of planktonic heterotrophic bacteria and accumulation of degradable DOC a normal phenomenon in phosphorus-limited systems? A microcosm study, FEMS Microbiology Ecology, 46, 307-316.

38. Valkanov A., 1934 - Contribution to hydrofauna of Bulgaria, Annals of the University of Sofia, 31, 149-285. (in Bulgarian, summary in German)

39. Vidakovic J. and Bogut I., 2004 - Aquatic nematodes of Sakadaš Lake (Kopački rit Nature Park, Croatia), Biologia, 59, 5, 567-575. 